\title{
Green and Optimum Extraction of Total Polyphenols Content from Mitragyna speciosa Korth. Havil Leaves using Microwave- Assisted Natural Deep Eutectic Solvent Extraction
}

\author{
Wisnu Cahyo Prabowo', Risna Agustina ${ }^{2}$, Yuspian Nur², Ramila Hidayati', Dewi Rahmawati', M. Arifuddin' \\ Neneng Siti Silfi Ambarwati ${ }^{3}$, Reza Yuridian Purwoko ${ }^{4}$, Abdul Mun'im5, Islamudin Ahmad ${ }^{1,2, *}$
}

\author{
Wisnu Cahyo Prabowo', Risna \\ Agustina ${ }^{2}$, Yuspian Nur ${ }^{2}$, Ramila \\ Hidayati', Dewi Rahmawati', \\ M. Arifuddin', Neneng Siti Silfi \\ Ambarwati ${ }^{3}$, Reza Yuridian \\ Purwoko ${ }^{4}$, Abdul Mun'im ${ }^{5}$, \\ Islamudin Ahmad ${ }^{1,2, *}$
}

'Laboratory of Pharmaceutical Research and Development of FARMAKA TROPIS, Faculty of Pharmacy, Universitas Mulawarman, Samarinda, 75119 East Kalimantan, INDONESIA.

${ }^{2}$ Department of Pharmaceutical Sciences, Faculty of Pharmacy, Universitas

Mulawarman, Samarinda, 75119 East Kalimantan, INDONESIA.

${ }^{3}$ Department of Cosmetology, Faculty of

Engineering, Universitas Negeri Jakarta, East Jakarta, 13220 Jakarta, INDONESIA. ${ }^{4}$ Faculty of Military Medicine, Universitas Pertahanan Rl, Bogor, 16810 West Java, INDONESIA.

${ }^{5}$ Department of Pharmaceutical Sciences, Faculty of Pharmacy, Universitas Indonesia, Depok, 16424 West Java, INDONESIA.

\section{Correspondence}

\section{Islamudin Ahmad}

Laboratory of Pharmaceutical Research and Development of FARMAKA TROPIS Department of Pharmaceutical Sciences, Faculty of Pharmacy, Universitas

Mulawarman, Samarinda, 75119 East

Kalimantan, INDONESIA.

Phone no. +6281342205060

E-mail: islamudinahmad@farmasi.unmul.ac.id History

- Submission Date: 08-10-2021;

- Review completed: 25-10-2021.

- Accepted Date: 10-11-2021.

DOI : 10.5530/pj.2022.14.5

Article Available online

http://www.phcogj.com/v14/i1

\section{Copyright}

(C) 2022 Phcogj.Com. This is an openaccess article distributed under the terms of the Creative Commons Attribution 4.0 International license.

\begin{abstract}
The current study mainly aims to apply and optimize the microwave-assisted natural deep eutectic solvent extraction (MANDESE) method of total polyphenol content from Mitragyna speciosa (Korth.) Havil leaves using response surface methodology (RSM) and its extraction mechanism using scanning electron microscopy (SEM) imaging. The extraction process was performed using the maceration and MANDESE method. Total polyphenols content was examined using Folin-Ciocalteu reagent and spectrophotometer UV-Vis. The extraction mechanism was performed using SEM imaging. The extraction condition as experimental design variable factors for optimization using RSM included NADES composition ratio, the liquid-solid ratio, extraction time, and microwave power. The results show that the MANDESE with some different combinations of NADES composition is more effective than a maceration. SEM imaging result shows that the levels of damage of cells and cell walls were more severe after extraction. The optimum extraction condition has obtained the NADES composition ratio of $3 \mathrm{~g} / \mathrm{g}$ (choline chloride/sorbitol) and the liquid-solid ratio of $20 \mathrm{~mL} / \mathrm{g}$ for 20 min extraction time with $60 \%$ Watts microwave power. The scale-up confirmation test was obtained the total polyphenols content of $526.12 \mu \mathrm{g}$ GAE/g sample. This finding demonstrated the optimum condition of the MANDESE method and performed efficiently, rapidly, safely, and environmentally friendly.

Key words: Microwave-assisted natural deep eutectic solvent extraction, Mitragyna speciosa (Kort.) Havil, Response surface methodology, Total polyphenols content.
\end{abstract}

\section{INTRODUCTION}

Mitragyna speciosa (Korth.) Havil is a native to Southeast Asia and belongs to the Rubiaceae family, the coffee family. $M$. speciosa is abundant and found growing in riverbanks, swampy areas, and inundated areas by water in some countries, such as Indonesia, Malaysia, Thailand, the Philippines, and Papua New Guinea. ${ }^{1}$ This plant has enormous potential as a source of raw materials for medicines with high export value. A local community traditionally uses the leaves of this plant to treat different diseases like fever, muscle pain, diarrhea, toughs, malarial, high blood pressure, diabetes mellitus, and worm diseases. ${ }^{2}$ Some studies have reported a pharmacological activity of $M$. speciosa leaves such as antinociceptive, ${ }^{3,4}$ antiinflammation, ${ }^{5}$ analgesic, ${ }^{6,7}$ opioid-like effects, ${ }^{8,9}$ and morphine withdrawal effect. ${ }^{10,11}$ However, legality is still constrained in its utilization related to the sedative effect caused by the high content of indole alkaloids. The content of major compounds in indole alkaloids is about $0.088 \%$, knowing that it can be separated using chloroform extraction up to $95 \%$. It can even reach $99 \%$ with some optimizations Beng et al. (2011) reported in laboratory experiments. ${ }^{12}$ This result proves that different extraction methods can avoid the unwanted effects of alkaloid compounds. Therefore, it is necessary to innovate to suppress alkaloids and increase the content of other beneficial metabolites, mainly polyphenols. Optimization needs to be done to increase the level of target secondary metabolite through a green extraction approach.

With the growth of "Green Chemistry" in recent years, green chemistry principles approaches have gained more traction. One of the most significant features of green technology is green solvents. Natural deep eutectic solvent (NADES) is a green solvent type made up of the primary metabolites of living organisms. It is often made up of ingredients abundant in our everyday diet, making it inexpensive, safe, and sustainable. ${ }^{13,14}$ NADES has emerged as a new type of green solvent with many good advantages, including biocompatibility, low toxicity, sustainability, ecological efficacy, and incredibly considerable solvent power. The eutectic mixtures have melting points below their components, usually above $150^{\circ} \mathrm{C} \cdot{ }^{15}$ NADES comprises at least one species of the hydrogen bond donor (HBD) and the hydrogen bond (HBA), which establishes strong interactions between hydrogen bonding after mixing, leading to eutectic mixtures that are usually liquid under room-close conditions. The most common NADES compositions and pharmaceutical excipients include citric acid, lactic acid, malic acid, choline chloride, sucrose, glucose, and sorbitol.

On the other hand, conventional extraction methods have been used for a long time, but this requires a longer time and a more significant number of solvents. This is the main weakness of the conventional method. Therefore, new extraction methods with reduced solvent consumption shortened extraction 
time and increased attention to pollution prevention. In comparison with conventional methods, microwave-assisted extraction can improve extraction efficiency by reducing time and solvent consumption. ${ }^{16}$ Thus, microwave-assisted natural deep eutectic solvent extraction (MANDESE) has excellent potential for extracting polyphenols compounds from natural products. MANDESE has risen rapidly in the last decade, and for most applications, it has proven to be effective in all aspects compared with conventional extraction techniques. Some studies have reported the application of the MANDESE method in extracting secondary metabolites from natural products, including extraction of alkaloids and polyphenols from Peumus boldus leaves, ${ }^{17}$ a flavonoid from Scutellaria baicalensis, ${ }^{18}$ polyphenols and caffeine from green coffee beans, ${ }^{19}$ bioactive compounds from Cinnamon Bark and Sappan Wood, ${ }^{20}$ anthocyanins from $C$. roseus. ${ }^{21}$ The application and optimization of the nonconventional MANDESE method on total polyphenols content extraction from $M$. speciosa leaves have never been reported.

In the current study, optimization of extraction condition of nonconventional MANDESE method performed using response surface methodology (RSM). RSM is a multi-factor mathematical and statistical test for the time and number of experimental samples. ${ }^{22}$ This method analyzes the impact of extraction factors to determine the best model from an optimum process combination of four factors and three-level using BoxBehnken Design. ${ }^{23}$ To obtain the optimum condition, we considered using four factors: NADES composition ratio, the liquid-solid ratio, extraction time, and microwave power that significantly contributed to the total polyphenol content extraction process based on the green extraction approach. RSM with Box-Behnken Design is very efficient to optimize the extraction conditions and to achieve the best predicted model. ${ }^{24,25}$

The purpose of this study, to apply and optimize the non-conventional MANDESE method on total polyphenols content from $M$. speciosa leaves. We also conducted scanning electron microscopy (SEM) imaging on both powder samples before and after the extraction process to describe better and clarify the extraction mechanism.

\section{MATERIALS AND METHODS}

\section{Materials and equipment}

The dried sample of M. speciosa leaves was obtained from Kota Bangun, Kutai Kertanegara, East Kalimantan, Indonesia. The voucher specimen (043/HKKC-LP/FF-UNMUL/II/2021) was identified and authenticated in the Laboratory of Dendrology, Faculty of Forestry, stored at Pharmaceutical Research and Development Laboratory of FARMAKA TROPIS, Faculty of Pharmacy, Universitas Mulawarman, Samarinda, East Kalimantan, Indonesia. Choline chloride, citric acid, sorbitol sucrose, glucose, lactic acid, and malic acid (100\% pure pharmaceutical excipient and food grade) were purchased from CV. Chlorogreen, Bandung, Indonesia. Folin-Ciocalteu reagent, sodium carbonate, and gallic acid were purchased from Sigma-Aldrich, Germany (PT. Elo Karsa, Indonesia). Aqua demineralization, methanol for analysis, ethyl acetate for analysis, and n-hexane were purchased from SmartLab Indonesia, Tangerang, Banten, Indonesia. The equipment used in this study include spectrophotometer UV-Vis double beam (Dynamica, Hallo DB 20S, UK), JEOL scanning electron microscope (JSM-5510LV), a modified domestic microwave (Modena ${ }^{\circ} 900$ Watts, USA), a domestic Food dehydrator (Wirastar', Indonesia), micropipettes (10-100 $\mu \mathrm{L}$ and $100-1000 \mu \mathrm{L}$, Socorex, Switzerland), a rotary vacuum evaporator (Rotavapor ${ }^{\oplus}$ R-215, Buchi, Flawil, Switzerland), and a licensed Design Expert v12 software (Stat-Ease, Minneapolis, MN, USA).

\section{Preparation of Natural Deep Eutectic Solvent (NADES)} as a Green Solvent

NADES preparation was conducted using different pharmaceutical excipient types, including citric acid and glucose, lactic acid and sucrose, malic acid and glucose, choline chloride, and sorbitol. Each NADES composition was prepared by heating and stirring each combination component at a specific ratio $(\mathrm{g} / \mathrm{g})$ in a tube at $60-80{ }^{\circ} \mathrm{C}$ accompanied by agitation at a speed of $3000 \mathrm{rpm}$ for 40 min constantly until a homogenous mixture was formed. Each mixture was added to aqua demineralization with a ratio of $1: 1 \mathrm{v} / \mathrm{v}$ and continued stirring to obtain a homogenous NADES solution. All NADES solutions obtained were stable in liquid form at room temperature storage.

\section{Extraction Process}

\section{Conventional Maceration Procedures}

The dried sample of $M$. speciosa leaves ( $5 \mathrm{~g}$ ) was extracted by the conventional maceration method using $50 \mathrm{~mL}$ ethanol $96 \%$ at room temperature for $3 \times 24$ hours. Then the extractant and the residue were separated using the Buchner funnel. The extract solution was evaporated to obtain the thick/dry extract.

Non-conventional Microwave-Assisted Natural Deep Eutectic Solvent Extraction Procedures

According to some previous studies, the extraction process was performed using the non-conventional microwave-assisted natural deep eutectic solvent extraction (MANDESE) method with modification. Briefly, a dried sample of $M$. speciosa leaves was extracted using microwave-assisted extraction combined with each combination of NADES composition under various conditions (Table 1). After the extraction process, the extract solution was separated with its residue by filtration using 0.45 cellulose acetate membrane and evaporated to dry using a domestic food dehydrator. The dry extract was stored in a tightly closed container until ready to use.

\section{Determination of Total Polyphenols Content}

The previous study determined total polyphenols contents using FolinCiocalteu reagent by spectrophotometry at the maximum wavelength with a range of $730-760 \mathrm{~nm} .{ }^{26}$ Briefly, standard and sample solution $(1 \mathrm{~mL})$ was added to $0.5 \mathrm{~mL}$ of Colin-Ciocalteu reagent and $5 \mathrm{~mL}$ of distilled water. The mixture was homogenized for $1 \mathrm{~min}$ and then allowed to stand for $4 \mathrm{~min}$. Then $1.5 \mathrm{~mL}$ distilled water and $2 \mathrm{~mL}$ sodium carbonate were added and homogenized for $1 \mathrm{~min}$. Next, the mixture of the sample test was incubated for one $h$ at room temperature. A spectrophotometer measured the absorbance at $746 \mathrm{~nm}$. Gallic acid solution with some different concentrations $(12.5,25,50,100$, and 200 $\mu \mathrm{g} / \mathrm{mL}$ ) was used as a standard to obtain a linear regression equation (1), $\mathrm{Y}=0.0022 \mathrm{X}-0.00095$, where $\mathrm{R} 2=0.9977$. Where coefficient correlation $\left(\mathrm{R}^{2}\right)$ value of 0.998 , $\mathrm{y}$ is absorbance, and $\mathrm{x}$ is total polyphenols content. The total polyphenols content (in $\mu \mathrm{g}$ GAE/g sample) was determined using this equation.

\section{Scanning Electron Microscopy Imaging}

Scanning electron microscopy (SEM) imaging was carried out to study the extraction mechanism and compare changes in the structure of the sample before and after the extraction process related to works of literature..$^{27,28,29}$ Briefly, each dried powder of sample (after and before

Table 1. Design Experimental (with Box-Behnken Design) of Response Surface Methodology (RSM) with a green solvent of choline chloride-sorbitol.

\begin{tabular}{lccccc}
\hline & & & \multicolumn{3}{c}{ Range and Level } \\
\cline { 5 - 6 } Factors & Unit & Symbol & Low (-1) & $\begin{array}{c}\text { Medium } \\
(0)\end{array}$ & High (1) \\
\hline $\begin{array}{lccccc}\text { NADES Composition } \\
\text { Ratio }\end{array}$ & $\mathrm{g} / \mathrm{g}$ & $\mathrm{X}_{1}$ & $1: 1$ & $2: 1$ & $3: 1$ \\
Liquid-Solid Ratio & $\mathrm{mL} / \mathrm{g}$ & $\mathrm{X}_{2}$ & 10 & 20 & 30 \\
Extraction Time & Minutes & $\mathrm{X}_{3}$ & 10 & 15 & 20 \\
Microwave Power & $\%$ Watts & $\mathrm{X}_{4}$ & 40 & 50 & 60
\end{tabular}


extraction) was plated on the carbon plate and coated with the spray of a nano-palladium-gold solution to form a conductive surface. Then, it was observed by SEM at $20 \mathrm{kV}$ operating voltage and under high vacuum conditions.

\section{Optimization of MANDESE Conditions using RSM}

Optimization of MANDESE condition was performed using BoxBehnken Design with four factors and three levels (in Table 1), with independent variables including NADES composition ratio $\left(\mathrm{X}_{1}\right)$, liquid-solid ratio $\left(\mathrm{X}_{2}\right)$, Extraction time $\left(\mathrm{X}_{3}\right)$, and microwave power $\left(\mathrm{X}_{4}\right)$. In contrast, the dependent variable is total polyphenols content as a response. Based on total polyphenols content extraction efficiency, all factors and levels were expected to achieve optimum MANDESE conditions significantly. The variation condition of MANDESE was simulated with RSM using Box-Behnken Design to obtain 29 experiment samples run. A total of 29 experiments were needed to build the math equation formula (2), ${ }^{30}$ as follow:

$$
Y=A_{0}+\sum_{i=1} A_{i i} X_{i}^{2}+\sum_{i=1 j}^{n} \sum_{=i+1}^{n} A_{i j} X_{i} X_{j}
$$

The regression model was calculated based on 29 experiments data from the independent and dependent variables by the multilinear quadratic model using the licensed Design Expert v12 program. The best and significant model was determined according to the $\mathrm{R}^{2}$ value and analysis of variance (ANOVA).

\section{RESULTS}

\section{Selection of NADES Compositions and Total Polyphenols Content Determination}

In the present study, the selection of solvent is an essential step in the extraction process. Some NADES compositions were used to determine the effectiveness of extraction on the total polyphenols content of $M$. speciosa leaves, compared with the conventional maceration extraction method using ethanol as a solvent (Figure 1). The extraction of the target secondary metabolites from the matrix sample of plants using several NADES compositions according to the solubility balance.

Figure 1 demonstrated that the extraction process using the nonconventional microwave-assisted natural deep eutectic solvent extraction (MANDESE) method (with some different NADES composition) has a higher efficiency of extracting the target secondary metabolite than the conventional maceration method. Meanwhile, the use of the NADES composition with various combinations of pharmaceutical excipient mixtures at the same ratio $(1: 1 \mathrm{~g} / \mathrm{g})$ showed differences in the ability to extract target secondary metabolite (total polyphenols content), including choline chloride-sorbitol, malic acid-glucose, citric acid-glucose, and lactic acid sucrose, respectively. Therefore, the combination of choline chloride-sorbitol was used as the NADES composition of green solvent to optimize the extraction condition using the MANDESE method. In this study, total polyphenols contents (in $\mu \mathrm{g} \mathrm{GAE} / \mathrm{g}$ sample) were calculated using equation (1).

\section{Scanning Electron Microscopy Imaging}

Scanning electron microscopy imaging was conducted to examine the effect of conventional maceration and non-conventional MANDESE methods and understand the extraction mechanism. Figure 2 shows the micrographs of the dried leave of samples before extraction (1), after extraction by maceration (2), and after extraction by the MANDESE method (3). The result shows that the levels of damage of cells and cell walls were more severe after extraction using the MANDESE method than the maceration method.

\section{Optimization of MANDESE Method Using RSM}

The MANDESE method was optimized using RSM to obtain the optimum extraction condition on total polyphenol content from $M$. speciosa leaves. The experimental design was built with four factors and three levels (Box-Behnken Design) using the licensed Design Expert v12 program, such as NADES ratio of choline chloride and sorbitol $(1: 1,2: 1$, and $3: 1 \mathrm{~g} / \mathrm{g})$, a liquid-solid ratio of NADES solution and dried leaves powder of sample $(10,20$, and $30 \mathrm{~mL} / \mathrm{g})$, extraction time (10, 15, and $20 \mathrm{~min}$ ), and microwave power (40, 50, and $60 \%$ watts). In this work, a total of 29 experiments were carried out according to the experimental design (Box-Behnken Design) of RSM to predict the optimum extraction condition of total polyphenols content from $M$. speciosa leaves (Table 2).

The extraction process According to the results obtained using the licensed Design Expert v12 program shows the highest total polyphenols content from $M$. speciosa leaves were obtained from run $24^{\text {th }}$ with the yield of $495.12 \mu \mathrm{g}$ GAE/g sample and the lowest the yield

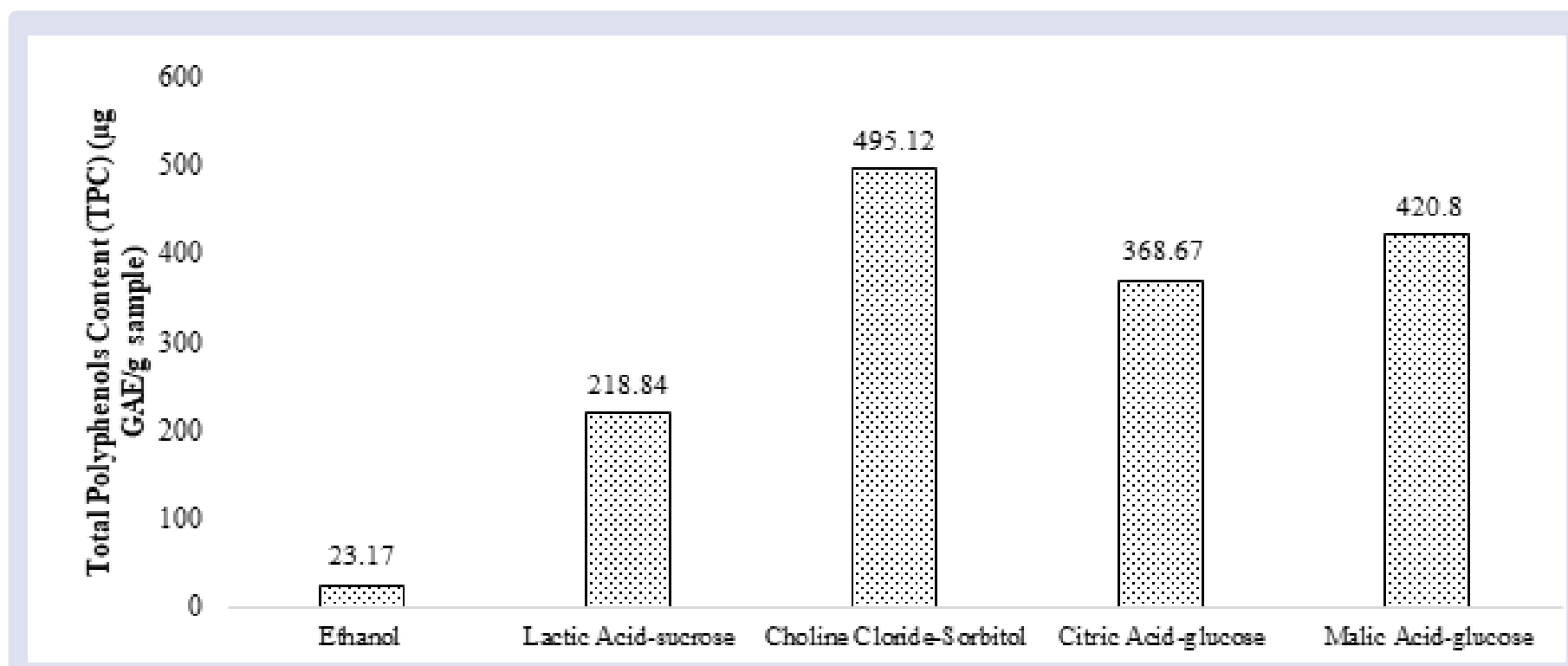

Figure 1. The results of total polyphenols content based on different NADES compositions for non-conventional MANDESE and ethanol for conventional maceration methods. 
Table 2. Box-Behnken Design (four factors and three levels) with observed predicted responses value of total polyphenols content ( $\mu$ g GAE/g sample) from $M$. speciosa leaves.

\begin{tabular}{|c|c|c|c|c|c|c|}
\hline \multirow{2}{*}{ Run } & \multicolumn{4}{|c|}{ Factors Variable } & \multicolumn{2}{|c|}{ Total polyphenol content ( $\mu \mathrm{g}$ GAE/g) } \\
\hline & $\mathrm{X}_{1}$ & $\mathrm{X}_{2}$ & $\mathrm{X}_{3}$ & $X_{4}$ & Observed & Predicted \\
\hline 1 & $1(-1)$ & $20(0)$ & $10(-1)$ & $50(0)$ & 129.37 & 129.37 \\
\hline 2 & $2(0)$ & $10(-1)$ & $15(0)$ & $40(-1)$ & 229.32 & 231.26 \\
\hline 3 & $2(0)$ & $30(1)$ & $15(0)$ & $40(-1)$ & 300.51 & 302.45 \\
\hline 4 & $2(0)$ & $30(1)$ & $15(0)$ & $60(1)$ & 361.07 & 359.13 \\
\hline 5 & $2(0)$ & $20(0)$ & $20(1)$ & $40(-1)$ & 119.46 & 119.46 \\
\hline 6 & $3(1)$ & $10(-1)$ & $15(0)$ & $50(0)$ & 231.70 & 231.70 \\
\hline 7 & $3(1)$ & $20(0)$ & $10(-1)$ & $50(0)$ & 321.71 & 321.71 \\
\hline 8 & $2(0)$ & $20(0)$ & $15(0)$ & $50(0)$ & 355.19 & 352.89 \\
\hline 9 & $3(1)$ & $20(0)$ & $15(0)$ & $40(-1)$ & 328.77 & 326.83 \\
\hline 10 & $2(0)$ & $20(0)$ & $15(0)$ & $50(0)$ & 343.18 & 352.89 \\
\hline 11 & $3(1)$ & $30(1)$ & $15(0)$ & $50(0)$ & 441.49 & 441.49 \\
\hline 12 & $1(-1)$ & $20(0)$ & $15(0)$ & $40(-1)$ & 163.14 & 161.20 \\
\hline 13 & $2(0)$ & $20(0)$ & $15(0)$ & $50(0)$ & 364.78 & 352.89 \\
\hline 14 & $2(0)$ & $10(-1)$ & $15(0)$ & $60(1)$ & 205.30 & 203.36 \\
\hline 15 & $1(-1)$ & $20(0)$ & $15(0)$ & $60(1)$ & 143.32 & 145.26 \\
\hline 16 & $2(0)$ & $20(0)$ & $15(0)$ & $50(0)$ & 349.34 & 352.89 \\
\hline 17 & $2(0)$ & $30(1)$ & $20(1)$ & $50(0)$ & 77.42 & 77.42 \\
\hline 18 & $2(0)$ & $10(-1)$ & $10(-1)$ & $50(0)$ & 263.30 & 263.30 \\
\hline 19 & $2(0)$ & $20(0)$ & $10(-1)$ & $60(1)$ & 42.12 & 42.12 \\
\hline 20 & $1(-1)$ & $30(1)$ & $15(0)$ & $50(0)$ & 369.80 & 269.80 \\
\hline 21 & $1(-1)$ & $10(-1)$ & $15(0)$ & $50(0)$ & 279.49 & 279.49 \\
\hline 22 & $3(1)$ & $20(0)$ & $15(0)$ & $60(1)$ & 369.61 & 371.54 \\
\hline 23 & $2(0)$ & $10(-1)$ & $15(0)$ & $50(0)$ & 108.21 & 108.21 \\
\hline 24 & $1(-1)$ & $20(0)$ & $20(1)$ & $50(0)$ & 495.12 & 495.12 \\
\hline 25 & $2(0)$ & $20(0)$ & $10(-1)$ & $40(-1)$ & 99.533 & 99.53 \\
\hline 26 & $2(0)$ & $20(0)$ & $15(0)$ & $50(0)$ & 351.97 & 352.89 \\
\hline 27 & $3(1)$ & $20(0)$ & $20(1)$ & $50(0)$ & 436.88 & 436.88 \\
\hline 28 & $2(0)$ & $20(0)$ & $20(1)$ & $60(1)$ & 423.28 & 423.28 \\
\hline 29 & $2(0)$ & $30(1)$ & $10(-1)$ & $50(0)$ & 436.67 & 436.67 \\
\hline
\end{tabular}

of $42.12 \mu \mathrm{g}$ GAE/g sample (run $19^{\text {th }}$ ), as can be seen in Table 2. The results of 29 experiment data were calculated to predict the optimum extraction condition of the MANDESE method using multilinear regression analysis. The best equation prediction regression model was obtained based on the calculation results using equation (2), as follows:

$\mathrm{Y}=352.89+97.98 \mathrm{X}_{1}+100.27 \mathrm{X}_{2}+56.74 \mathrm{X}_{3}+7.19 \mathrm{X}_{4}-62.65 \mathrm{X}_{1} \mathrm{X}_{2}+$ $29.87 \mathrm{X}_{1} \mathrm{X}_{3}+15.16 \mathrm{X}_{1} \mathrm{X}_{4}-51.04 \mathrm{X}_{2} \mathrm{X}_{3}+90.31 \mathrm{X}_{2} \mathrm{X}_{4}+21.15 \mathrm{X}_{3} \mathrm{X}_{4}-$ $37.11 \mathrm{X}_{1}^{2}-117.22 \mathrm{X}_{2}^{2}-14.27 \mathrm{X}_{3}^{2}-64.57 \mathrm{X}_{4}^{2}+19.98 \mathrm{X}_{1}^{2} \mathrm{X}_{2}+18.28 \mathrm{X}_{1}^{2} \mathrm{X}_{3}$ $-64.45 \mathrm{X}_{1}{ }^{2} \mathrm{X}_{2}{ }^{2}-2 \mathrm{X}_{1} \mathrm{X}_{3}{ }^{2}-21.1 \mathrm{X}_{2}{ }^{2} \mathrm{X}_{3}+54.41 \mathrm{X}_{2}{ }^{2} \mathrm{X}_{4}-228.85 \mathrm{X}_{2} \mathrm{X}_{3}^{2}+$ 147.21 $\mathrm{X}_{1}^{2} \mathrm{X}_{2}^{2}+29.11 \mathrm{X}_{1}^{2} \mathrm{X}_{3}^{2}$

Where coefficient correlation $\left(\mathrm{R}^{2}\right)$ value of $0.9994, \mathrm{Y}$ is total polyphenols content ( $\mu \mathrm{g}$ GAE/g sample), $\mathrm{X}_{1}$ is NADES composition ratio $(\mathrm{g} / \mathrm{g}), \mathrm{X}_{2}$ is extraction time $(\mathrm{min}), \mathrm{X}_{3}$ is a liquid-solid ratio $(\mathrm{mL} / \mathrm{g})$, and $\mathrm{X}_{4}$ is microwave power (\%Watts).

Table 3, based on the analysis of variance (ANOVA) from total polyphenols content, shows that the resulting model has a significant effect on the total polyphenols content with an F-value of 341.70 (refers to $\mathrm{p}$-value $<0.05$ ), where a $0.01 \%$ chance the F-value can occur due to an error or interference. In this case, $\mathrm{X}_{1}, \mathrm{X}_{2}, \mathrm{X}_{3}, \mathrm{X}_{4}, \mathrm{X}_{1} \mathrm{X}_{2}, \mathrm{X}_{1} \mathrm{X}_{3}, \mathrm{X}_{1} \mathrm{X}_{4}$, $\mathrm{X}_{2} \mathrm{X}_{3}, \mathrm{X}_{2} \mathrm{X}_{4}, \mathrm{X}_{3} \mathrm{X}_{4}, \mathrm{X}_{1}^{2}, \mathrm{X}_{2}^{2}, \mathrm{X}_{3}^{2}, \mathrm{X}_{4}^{2}, \mathrm{X}_{1}^{2} \mathrm{X}_{2}, \mathrm{X}_{1}^{2} \mathrm{X}_{3}, \mathrm{X}_{1} \mathrm{X}_{2}^{2}, \mathrm{X}_{1} \mathrm{X}_{3}^{2}, \mathrm{X}_{2}^{2} \mathrm{X}_{3}$, $\mathrm{X}_{2}^{2} \mathrm{X}_{4}, \mathrm{X}_{1}^{2} \mathrm{X}_{2}^{2}, \mathrm{X}_{1}^{2} \mathrm{X}_{3}^{2}$ are significant model term. On the other hand, the F-value of "Lack of Fit" was 0.47 (with a p-value of 0.5293), which indicated that the $p$-value $>0.005$ was not significant to the pure error. There is a $52.93 \%$ chance that a Lack of Fit F-value this large could occur due to noise. In addition, the optimum condition from the equation model can be applied as navigation to design the desired optimum extraction condition.
In Table 4, the coefficient estimates represent the expected change in response per unit in factor value when all other factors are constant. Orthogonal design intercept is the overall average response of all analyses. The coefficient fits the mean based on the coefficient set. If the factors are orthogonal, the variance inflation factor (VIF) is 1. VIF greater than 1 indicates multicollinearity, and the higher the VIF, the stronger the correlation of the factors. As a hard rule, a VIF below 10 is acceptable. The equation in phrases of codec factors can be applied to predict approximately the response for given tiers of every factor. By default, the excessive tiers of the factors are coded as +1 , and low tiers are coded as -1 . The codec equation is beneficial for figuring out the relative effect of the factor through evaluating the factor coefficients.

The three-dimension (3D) response graph and contour plot for the effect of various extraction variable factors on total polyphenol content was presented in Figure 3. It demonstrated that the curvature of these plots indicates the interaction and relationship between each factor that are variable parameters of extraction condition, including microwave power and NADES composition ratio; microwave power and extraction time; microwave power and liquid-solid ratio; extraction time and liquid-solid ratio; liquid-solid ration and NADES composition ratio; and Extraction time and NADES composition ratio. In general, with view glance from the results, the efficiency of polyphenols extraction from this plant was strongly influenced by these various variable factors used.

\section{DISCUSSION}

In the present study, the NADES composition combined with choline chloride and sorbitol as a green solvent extracted secondary metabolites with the highest total polyphenol content compared with 
Prabowo WC, et al.: Green and Optimum Extraction of Total Polyphenols Content from Mitragyna speciosa Korth. Havil Leaves using Microwave-Assisted Natural Deep Eutectic Solvent Extraction

Table 3. Analysis of Variance (ANOVA) for response surface by the regression model.

\begin{tabular}{|c|c|c|c|c|c|}
\hline Source & Sum of Squares & df & Mean Square & F-Value & p-Value \\
\hline Model & 0.00004470 & 23 & 19435.86 & 341.70 & $<0.0001$ \\
\hline $\mathrm{X}_{1}$ & 38397.77 & 1 & 38397.77 & 675.07 & $<0.0001$ \\
\hline $\mathrm{X}_{2}$ & 12878.28 & 1 & 12878.28 & 226.41 & $<0.0001$ \\
\hline $\mathrm{X}_{3}$ & 40216.09 & 1 & 40216.09 & 707.04 & $<0.0001$ \\
\hline $\mathrm{X}_{4}$ & 414.09 & 1 & 414.09 & 7.28 & 0.0429 \\
\hline $\mathrm{X}_{1} \mathrm{X}_{2}$ & 3568.63 & 1 & 3568.63 & 62.74 & 0.0005 \\
\hline $\mathrm{X}_{1} \mathrm{X}_{3}$ & 15697.71 & 1 & 15697.71 & 275.98 & $<0.0001$ \\
\hline $\mathrm{X}_{1} \mathrm{X}_{4}$ & 919.70 & 1 & 919.70 & 16.17 & 0.0101 \\
\hline $\mathrm{X}_{2} \mathrm{X}_{3}$ & 10419.82 & 1 & 10419.82 & 183.19 & $<0.0001$ \\
\hline $\mathrm{X}_{2} \mathrm{X}_{4}$ & 1788.74 & 1 & 1788.74 & 31.45 & 0.0025 \\
\hline $\mathrm{X}_{3} \mathrm{X}_{4}$ & 32620.51 & 1 & 32620.51 & 573.50 & $<0.0001$ \\
\hline $\mathrm{X}_{1}^{2}$ & 2825.30 & 1 & 2825.30 & 49.67 & 0.0009 \\
\hline $\mathrm{X}_{2}^{2}$ & 857.40 & 1 & 857.40 & 15.07 & 0.0116 \\
\hline $\mathrm{X}_{3}^{2}$ & 57858.78 & 1 & 57858.78 & 1017.22 & $<0.0001$ \\
\hline $\mathrm{X}_{4}^{2}$ & 17555.96 & 1 & 17555.96 & 308.65 & $<0.0001$ \\
\hline $\mathrm{X}_{1}^{2} \mathrm{X}_{2}$ & 668.48 & 1 & 668.48 & 11.75 & 0.0187 \\
\hline $\mathrm{X}_{1}^{2} \mathrm{X}_{3}$ & 796.80 & 1 & 796.80 & 14.01 & 0.0134 \\
\hline $\mathrm{X}_{1} \mathrm{X}_{2}^{2}$ & 16928.28 & 1 & 16928.28 & 297.62 & $<0.0001$ \\
\hline $\mathrm{X}_{1} \mathrm{X}_{3}^{2}$ & 8308.77 & 1 & 8308.77 & 146.08 & $<0.0001$ \\
\hline $\mathrm{X}_{2}^{2} \mathrm{X}_{3}$ & 0.00001047 & 1 & 0.00001047 & 1841.60 & $<0.0001$ \\
\hline $\mathrm{X}_{2} \mathrm{X}_{3}^{2}$ & 890.25 & 1 & 890.25 & 15.65 & 0.0108 \\
\hline $\mathrm{X}_{3}^{2} \mathrm{X}_{4}$ & 7893.59 & 1 & 7893.59 & 138.78 & $<0.0001$ \\
\hline $\mathrm{X}_{1}^{2} \mathrm{X}_{2}^{2}$ & 847.14 & 1 & 847.14 & 14.89 & 0.0119 \\
\hline $\mathrm{X}_{1}^{2} \mathrm{X}_{3}^{2}$ & 21670.93 & 1 & 21670.93 & 381.00 & $<0.0001$ \\
\hline Residual & 284.40 & 5 & 56.88 & & \\
\hline Lack of Fit & 30.09 & 1 & 30.09 & 0.4732 & 0.5293 \\
\hline Pure Error & 254.31 & 4 & 63.58 & & \\
\hline Cor Total & 0.00004473 & 28 & & & \\
\hline
\end{tabular}

Table 4. Coefficient Estimate (CE), Standard Error (SE), Confidence Interval (CI), and Variance Inflation Factor (VIF) of the modified quadratic regression model.

\begin{tabular}{|c|c|c|c|c|c|c|}
\hline \multirow{2}{*}{ Factor } & \multirow{2}{*}{$\begin{array}{l}\text { Coefficient Estimate } \\
\text { (CE) }\end{array}$} & \multirow{2}{*}{ df } & \multirow{2}{*}{ Standard Error (SE) } & \multicolumn{2}{|c|}{ 95\% Confidence Interval (CI) } & \multirow{2}{*}{$\begin{array}{c}\text { Variance Inflation } \\
\text { Factor (VIF) }\end{array}$} \\
\hline & & & & Low & High & \\
\hline Intercept & 352.89 & 1 & 3.37 & 344.22 & 361.56 & - \\
\hline $\mathrm{X}_{1}$ & 97.98 & 1 & 3.77 & 88.28 & 107.67 & 3.0000 \\
\hline $\mathrm{X}_{2}$ & 56.74 & 1 & 3.77 & 47.05 & 66.43 & 3.0000 \\
\hline $\mathrm{X}_{3}$ & 100.27 & 1 & 3.77 & 90.58 & 109.96 & 3.0000 \\
\hline $\mathrm{X}_{4}$ & 7.19 & 1 & 2.67 & 0.3402 & 14.05 & 1.5000 \\
\hline $\mathrm{X}_{1} \mathrm{X}_{2}$ & 29.65 & 1 & 3.77 & 20.18 & 39.56 & 1.0000 \\
\hline $\mathrm{X}_{1} \mathrm{X}_{3}$ & -62.65 & 1 & 3.77 & -72.34 & -52.95 & 1.0000 \\
\hline $\mathrm{X}_{1} \mathrm{X}_{4}$ & 15.15 & 1 & 3.77 & 5.47 & 24.68 & 1.0000 \\
\hline $\mathrm{X}_{2} \mathrm{X}_{3}$ & -51.04 & 1 & 3.77 & -60.73 & -41.35 & 1.0000 \\
\hline $\mathrm{X}_{2} \mathrm{X}_{4}$ & 21.15 & 1 & 3.77 & 11.45 & 30.84 & 1.0000 \\
\hline $\mathrm{X}_{3} \mathrm{X}_{4}$ & 90.31 & 1 & 3.77 & 80.61 & 100.00 & 1.0000 \\
\hline $\mathrm{X}_{1}^{2}$ & -37.11 & 1 & 5.27 & -50.65 & -23.58 & 3.0000 \\
\hline $\mathrm{X}_{2}^{2}$ & -14.27 & 1 & 3.68 & -23.72 & -4.82 & 1.6700 \\
\hline $\mathrm{X}_{3}^{2}$ & -117.22 & 1 & 3.68 & -122.67 & -107.78 & 1.6700 \\
\hline $\mathrm{X}_{4}^{2}$ & -64.57 & 1 & 3.68 & -74.02 & -55.12 & 1.6700 \\
\hline $\mathrm{X}_{1}^{2} \mathrm{X}_{2}$ & 18.28 & 1 & 5.33 & 4.57 & 31.99 & 2.0000 \\
\hline $\mathrm{X}_{1}^{2} \mathrm{X}_{3}$ & 19.96 & 1 & 5.33 & 6.25 & 33.67 & 2.0000 \\
\hline $\mathrm{X}_{1} \mathrm{X}_{2}^{2}$ & -92.00 & 1 & 5.33 & -105.71 & -78.29 & 2.0000 \\
\hline $\mathrm{X}_{1} \mathrm{X}_{3}{ }^{2}$ & -64.45 & 1 & 5.33 & -78.16 & -50.75 & 2.0000 \\
\hline $\mathrm{X}_{2} \mathrm{X}_{3}{ }^{2}$ & -21.10 & 1 & 5.33 & -34.81 & -7.39 & 2.0000 \\
\hline $\mathrm{X}_{2}^{2} \mathrm{X}_{3}$ & -228.85 & 1 & 5.33 & -242.56 & -215.15 & 2.0000 \\
\hline $\mathrm{X}_{3}^{2} \mathrm{X}_{4}$ & 54.41 & 1 & 4.62 & 42.53 & 66.28 & 1.5000 \\
\hline $\mathrm{X}_{1}^{2} \mathrm{X}_{2}^{2}$ & 147.21 & 1 & 7.54 & 127.82 & 166.69 & 3.4500 \\
\hline $\mathrm{X}_{1}^{2} \mathrm{X}_{3}^{2}$ & 29.11 & 1 & 7.54 & 9.72 & 48.49 & 3.4500 \\
\hline
\end{tabular}




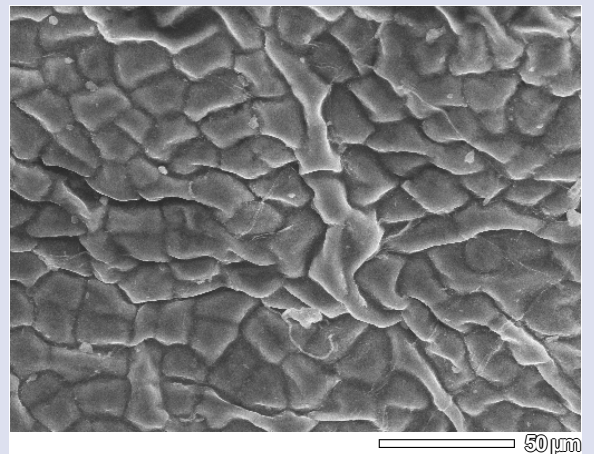

(1)

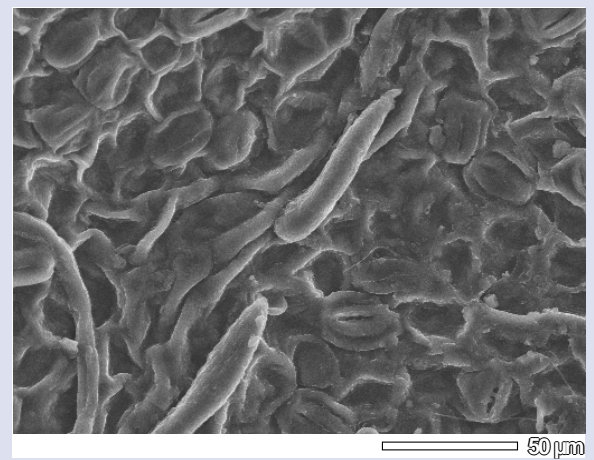

(2)

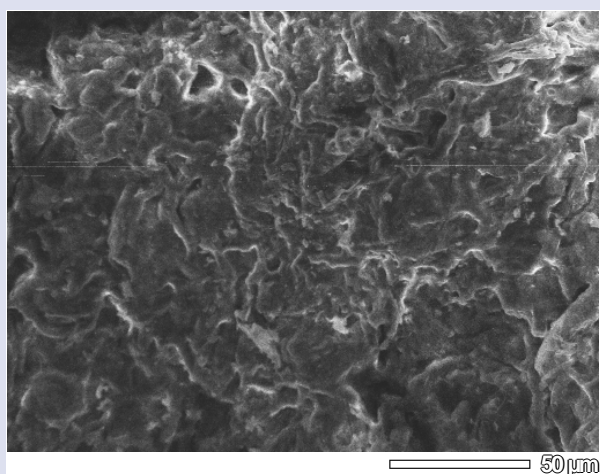

(3)

Figure 2. The Micrograph of SEM imaging results of the dried leaves powder of sample, (1) before treatment, (2) after maceration treatment, and (3) after MANDESE treatment.

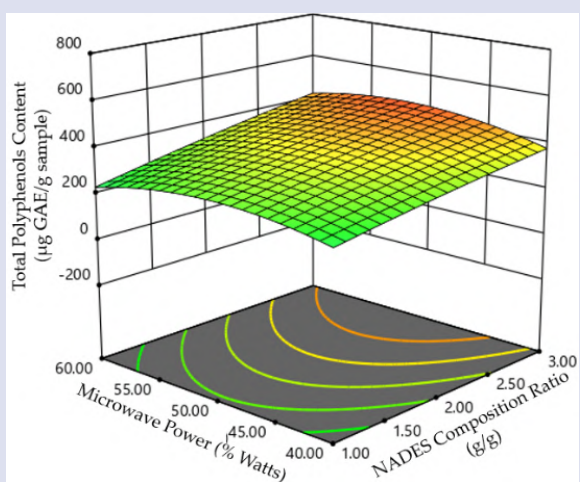

A

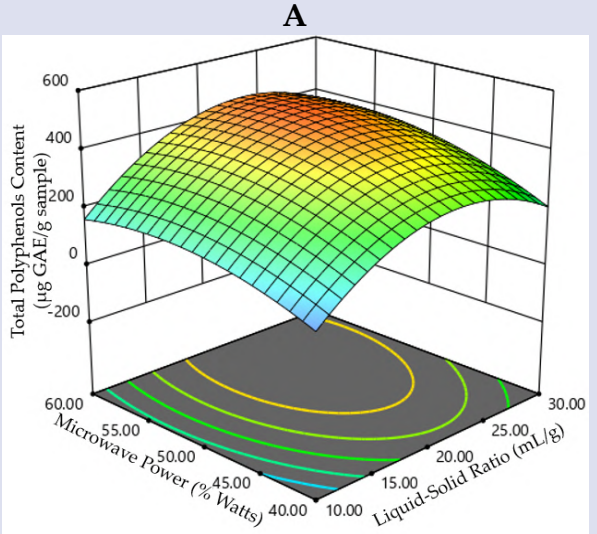

C

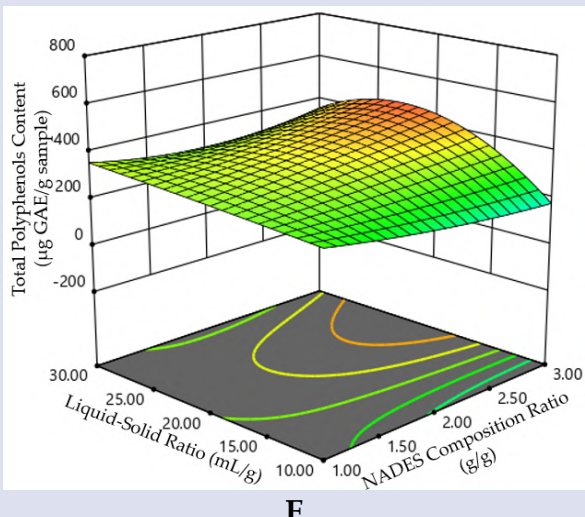

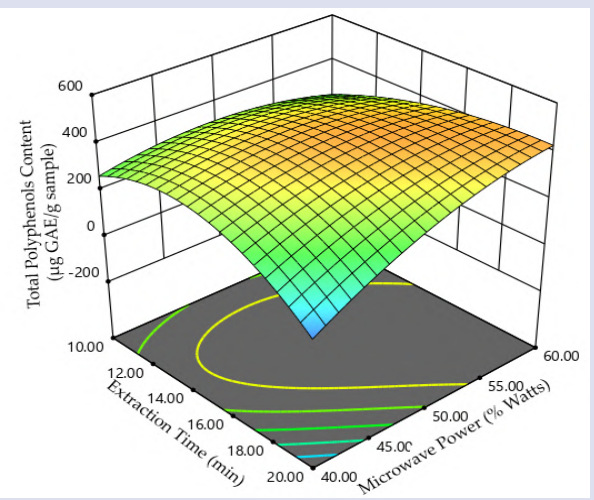

B

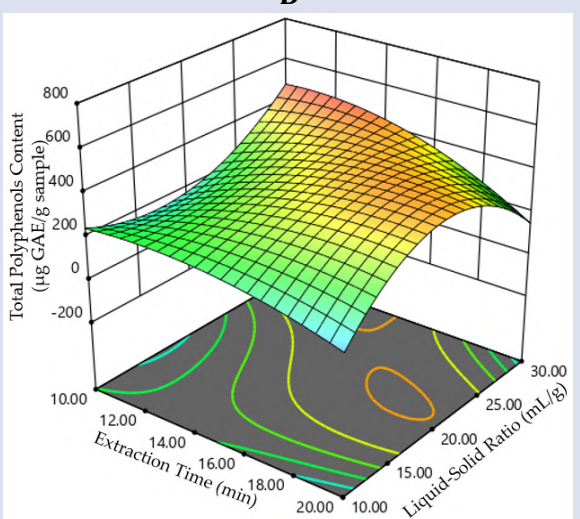

D

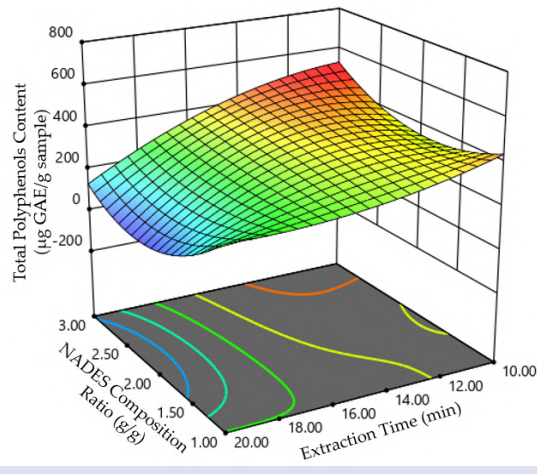

$\mathbf{F}$

Figure 3. The influence of variable factors on TPC extraction from M. speciosa include power and NADES composition ratio (A); power and time (B); power and liquid-solid ratio (C); time and liquid-solid ratio (D); liquid-solid and NADES ratio (E); time and NADES ratio (F). 
conventional organic ethanol solvent and other NADES compositions. The above results show that a green solvent of NADES composition with choline chloride-sorbitol was more effective than the others. This solvent is twenty times as strong as that of ethanol. Other parameters, such as microwave power, extraction time, and liquid-solid ratio, also significantly impact the extraction efficiency. As a result, it becomes the essential aspect to consider in selecting these four factors in optimizing the extraction conditions.

On the other hand, the non-conventional microwave-assisted natural deep eutectic solvent extraction (MANDESE) method provides several advantages, including non-volatile, low-toxicity, operator convenience and safety, and environmentally friendliness, ${ }^{20,31,32}$ as well as being available in the laboratory. This result is in line with the results of SEM imaging, which shows that the level of cell wall damage in the sample matrix has a good correlation with the level of extraction efficiency. Each extraction method, which is compared to the sample matrix before the extraction procedure for both samples, can demonstrate physical, structural changes in the cell wall of the sample matrix. The effect of the extraction process on the extent of damage to the cell wall matrix of samples has been revealed in several papers. ${ }^{29,33,34}$

Based on our findings, the optimum condition of the MANDESE method was obtained regarding the RSM analysis result using the licensed Design Expert v12 software as follows: NADES composition ratio of $3 \mathrm{~g} / \mathrm{g}$ (choline chloride/sorbitol) and the liquid-solid ratio of $20 \mathrm{~mL} / \mathrm{g}$ for $20 \mathrm{~min}$ extraction time with $60 \%$ Watts microwave power with total polyphenols content prediction of $539.37 \mu \mathrm{g}$ GAE/g sample of M. speciosa leaves. We performed a scale-up confirmation test to prove the accuracy of the prediction of the optimum conditions obtained. A $50 \mathrm{~g}$ dried sample of $M$. speciosa leaves was extracted under the recommended optimum conditions, providing the approximately total polyphenols content value of $526.12 \mu \mathrm{g}$ GAE/g sample (with a standard deviation of 5.418 in triple repetition).

A combination of choline chloride and sorbitol with various ratios from 1 to $3 \mathrm{~g} / \mathrm{g}$ was used in this study. The interaction impact of many aspects and sample characteristics contribute to the variation in optimum conditions. NADES composition with choline chloride and sorbitol was chosen and implemented in this study based on the selectivity efficiency in extracting total polyphenols content. Both materials mix solids and liquids, with sorbitol acting as a hydrogen-bonding donor (HBD) and choline chloride acting as a hydrogen bond acceptor (HBA) ${ }^{35,36,37}$ At temperatures less than $100^{\circ} \mathrm{C}$, the deep eutectic solvent in liquid was formed by adjusting the NADES composition ratio at a specific proportion (HBD and HBA mixture). ${ }^{38,37}$

Furthermore, different liquid-solid ratios, such as 10,20 , and $30 \mathrm{~mL} / \mathrm{g}$ was used to test the effect. In this work, the increase in the liquidsolid ratio causes maximal direct contact between target secondary metabolites and the green solvent in the matrix sample under these conditions.$^{39}$ However, if it is too large or has a high ratio, it will cause a waste of material used. A low ratio can result in an inefficient extraction process. ${ }^{40}$ The optimum condition of the MANDESE method with NADES composition and the liquid-solid ratio was $3 \mathrm{~g} / \mathrm{g}$ (choline chloride-sorbitol) and $20 \mathrm{~mL} / \mathrm{g}$ (NADES solution-sample).

While the influence of various conditions of the extraction equipment, such as microwave power and extraction time, dramatically affects the level of extraction efficiency of the total polyphenol content. In this study, the effect of microwave power was tested at various levels extending from 40 to $60 \%$ Watts. When the microwave power is increased, the temperature rises. A temperature increase that is too high can damage the sample matrix and generate a change in the target compound's structure. ${ }^{16,26}$ The extraction process was carried out in different time variations, including 10, 15, and $20 \mathrm{~min}$, based on some previous studies. ${ }^{41}{ }^{43}$ This result shows that the highest total polyphenols content of M. speciosa leaves was achieved at 20 minutes for optimal extraction time. This situation shows that the dissolution process of the target secondary metabolite in the sample is in equilibrium ${ }^{44}$. Based on these two conditions, there is a tendency to increase the yield of the total polyphenol content. However, the increase in microwave power and extraction time was limited because the resulting temperature could not be regulated. Excessive temperatures should be avoided because most secondary metabolites decompose at high temperatures.

Overall, these findings indicate that various variable factors used proved to significantly affect the extraction efficiency of total polyphenols from M. speciosa leaves. However, our findings should be interpreted with caution, given several limitations. First, the target secondary metabolites (total polyphenols content) are compounds measured using the UV-Vis spectrophotometry method with Folin-Ciocalteu reagent, calculated based on equivalence and only using standard gallic acid. Therefore, prospective studies using pure compounds as the target to ensure the selectivity of green solvent media used with more sensitive analytical methods (e.g., HPLC) are needed to confirm our findings. Second, in this study, only four combinations of excipients were used as the composition of NADES, so that the best NADES composition used had not been compared with other materials that may have high selectivity potential when used as a solvent. Third, the selectivity of the target compound only focuses on the efficiency level concerning polyphenol levels, has not considered the possibility of other secondary metabolite groups, so further analysis is needed.

Despite these limitations, to the best of our knowledge, this is the first time reported regarding the use and optimization of the MANDESE method to increase the efficiency of polyphenol extraction from M. speciosa leaves. This finding adds to information related to the use of NADES as a green solvent and optimum medium for extracting target secondary metabolites (especially the polyphenol group), considering that this group of compounds from plants has not been widely studied developed for its benefits.

\section{ACKNOWLEDGMENTS}

This research was funded by Direktorat Riset dan Pengabdian Masyarakat Deputi Bidang Penguatan Riset dan Pengembangan Kementerian Riset dan Teknologi/Badan Riset dan Inovasi, via Hibah Penelitian Dasar Unggulan Perguruan Tinggi (PDUPT) with a grant number: 036/SP2H/LT/DRPM/2021 and 580/UN17.L1/PG/2021.

\section{CONFLICTS OF INTEREST}

The authors declared no conflicts of interest.

\section{REFERENCES}

1. Ridsdale CE. A revision of Mitragyna and Uncaria (Rubiaceae). Blumea. 1978; 24: 43-100.

2. Singh D, Narayanan S, Vicknasingam B. Traditional and nontraditional uses of Mitragynine (Kratom): A survey of the literature. Brain Res Bull. 2016; 126: 41-46.

3. Luliana S, Islamy MR. Antinociceptive activity of dichloromethane fraction of Kratom leaves (Mitragyna speciosa Korth.) by oral route in male swiss mice. Pharm Sci Res. 2018; 5(2): 58-64.

4. Hiranita $T$, Leon F, Felix JS, Restrepo LF, Reeves ME, Pennington AE, Obeng S, Avery BA, McCurdy CR, McMahon LR, Wilkerson JL. The effects of mitragynine and morphine on schedule-controlled responding and antinociception in rats. Psychopharmacol. 2020; 236(9): 2725-2734

5. Tohar N, Shilpi JA, Sivasothy Y, Ahmad S, Awang K. Chemical constituents and nitric oxide inhibitory activity of supercritical carbon dioxide extracts from Mitragyna speciosa leaves. Arab J Chem. 2019; 12(3): 350-359. 
6. Reanmongkol W, Keawpradub N, Sawangjaroen K. Effects of the extracts from Mitragyna speciosa Korth. leaves on analgesic and behavioral activities in experimental animals. Songklanakarin J Sci Technol. 2007; 29: 39-48.

7. Ya K, Tangamornsuksan W, Scholfield CN, Methaneethorn J, Lohitnavy M. Pharmacokinetics of mitragynine, a major analgesic alkaloid in kratom (Mitragyna speciosa): A systematic review. Asian J Psychiatr. 2019; 43: 73-82.

8. Kruegel AC, Uptery R, Grinnell SG, Langreck C, Pekarskaya EA, Le Rouzic V, Ansonoff M, Gassaway MM, Pintar JE, Pasternak GW, Javitch JA, Majumdar S, Sames D. 7-Hydroxymitragynine is an active metabolite of mitragynine and a key mediator of its analgesic effects. ACS Cent Sci. 2019; 5(6): 992-1001.

9. Kaye AD, Cornett EM, Patil SS, Gennuso SA, Colontonio MN Latimer DR, Kaye AJ, Urman RD, Vadivelu N. New opioid receptor modulators and agonists. Best Pract Res Clin Anaesthesiol. 2018; 32(2): 125-136.

10. Hassan R, Pike See C, Sreenivasan S, Mansor SM, Müller CP, Hassan Z. Mitragynine attenuates morphine withdrawal effects in rats-A comparison with methadone and buprenorphine. Front Psychiatry. 2020; 11: 1-13

11. Saingam D, Assanangkornchai S, Geater AF, Lerkiatbundit S. Factor analytical investigation of krathom (Mitragyna speciosa Korth.) withdrawal syndrome in Thailand. J Psychoactive Drugs. 2016; 48(2): 76-85.

12. Beng GT, Hamdan MR, Siddiqui MJ, Mordi MN, Mansor SM. A simple and cost effective isolation and purification protocol of mitragynine from Mitragyna speciosa korth (ketum) leaves. Malaysian J Anal Sci. 2011; 15(1): 54-60.

13. Dai Y, Spronsen JV, G. W, Verporte R, Choi YH. Natural deep eutectic solvents as new potential media for green technology. Anal Chim Acta. 2013; 766: 61-68.

14. Savi LK, Dias MCGC, Carpine D, Waszczynskyj N, Ribani RH, Haminiuk CWI. Natural deep eutectic solvents (NADES) based on citric acid and sucrose as a potential green technology: a comprehensive study of water inclusion and its effect on thermal, physical and rheological properties. Int J Food Sci Technol. 2018; 54(3): 898-907

15. Liu Y, Friesen JB, Mcalpine JB, Lankin DC, Chen S, Pauli GF. Natural deep eutectic solvents: Properties, applications, and perspectives. J Nat Prod. 2018; 81: 679-690.

16. Ahmad I, Yanuar A, Mulia K, Mun'im A. Ionic liquid-based microwave-assisted extraction: Fast and green extraction method of secondary metabolite on medicinal plant. Pharmacogn Rev. 2018; 12(23): 20-26.

17. Torres-Vega J, Gomez-Alonso S, Perez-Navarro J, PasteneNavarrete E. Green extraction of alkaloids and polyphenols from Peumus boldus leaves with natural deep eutectic solvents and profiling by HPLC-PDA-IT-MS/MS and HPLC-QTOF-MS/MS. Plants. 2020; 9: p. 242

18. Oomen WW, Begines $P$, Mustafa NR, Wilson EG, Verpoorte $R$, Choi YH. Natural deep eutectic solvent extraction of flavonoids of Scutellaria baicalensis as a replacement for conventional organic solvents. Molecules. 2020; 25: p. 617.

19. Ahmad I, Miftah A, Azminah A, Chany F, Mun A. Optimization of betaine-sorbitol natural deep eutectic solvent-based ultrasoundassisted extraction and pancreatic lipase inhibitory activity of chlorogenic acid and caffeine content from robusta green coffee beans. Heliyon. 2021; 7(8): p. e07702.

20. Ahmad I, Arifianti AE, Sakti AS, Saputri FC, Mun'im A. Simultaneous natural deep eutectic solvent-based ultrasonic-assisted extraction of bioactive compounds of Cinnamon bark and Sappan wood as a dipeptidyl peptidase IV inhibitor. Molecules. 2020; 25: p. 3832.
21. Dai $Y$, Rozema E, Verpoorte R, Choi YH. Application of natural deep eutectic solvents to the extraction of anthocyanins from Catharanthus roseus with high extractability and stability replacing conventional organic solvents. J Chromatogr A. 2016; 1434: 50-56.

22. Dahmoune F, Nayak B, Moussi K, Remini H, Madani K. Optimization of microwave-assisted extraction of polyphenols from Myrtus communis L. leaves. Food Chem. 2015; 166: 585-595.

23. Meeker W, Hahn G, Escobar L. Statistical Interval, A Guide for Practioner and Researcher. 2nd Editio. John Wiley and Sons, Inc; 2017

24. Piepel G, Szychowski J, Leoppky J. Augmenting scheffe linear mixture models with squared and/or crossproduct terms. J Qual Technol. 2002; 34(3): 297-314.

25. Brusco MJ, Steinley D, Cradit JD. An exact algorithm for hierarchically well-formulated subsets in second-order polynomial regression. Technometrics. 2009; 51(3): 306-315.

26. Herman, Ibrahim A, Rahayu BP, Arifuddin M, Nur Y, Prabowo WC Maryono, Ambarwati NSS, Rijai L, Ahmad I. Single factor effect of natural deep eutectic solvent citric acid-glucose based microwaveassisted extraction on total polyphenols content from Mitragyna speciosa Korth. Havil leaves. Pharmacogn J. 2021; 13(5): 11091115

27. Liu T, Sui X, Zhang R, Yang L, Zu Y, Zhang L. Application of ionic liquids based microwave-assisted simultaneous extraction of carnosic acid, rosmarinic acid and essential oil from Rosmarinus officinalis. J Chromatogr A. 2011; 1218(47): 8480-8489.

28. Khademi A, Saatchi M, Mehdi M, Baghaei B. Scanning electron microscopic evaluation of residual smear layer following preparation of curved root canals using hand instrumentation of two enginecriven systems. Iran Endod J. 2015; 10(4): 236-239.

29. Ahmad I, Yanuar A, Mulia K, Mun'im A. Application of ionic liquid as a green solvent for polyphenolics content extraction of Peperomia pellucida (L) Kunth herb. J Young Pharm. 2017; 9(4): 486-490.

30. Peng Y, Khaled U, Al-Rashed AAAA, Meer R, Goodarzi M, Sarafraz MM. Potential application of Response Surface Methodology (RSM) for the prediction and optimization of thermal conductivity of aqueous CuO (II) nanofluid: A statistical approach and experimenta validation. Phys A Stat Mech its Appl. 2020; 554: 124353

31. Paiva A, Creveiro R, Aroso I, Martins M, Reis RL, Duarte ARC Natural deep eutectic solvents - solvents for the $21^{\text {st }}$ century. Am Chem Soc Sustain Chem Eng. 2014; 2: 1063-1071.

32. Espino M, Fernández M de los Á, Gomez FJV, Boiteux J, Silva MF. Green analytical chemistry metrics: Towards a sustainable phenolics extraction from medicinal plants. Microchem J. 2018; 141: 438-443.

33. Ding X, Li L, Wang Y, Chen J, Huang Y, Xu K. Design of guanidinium ionic liquid based microwave-assisted extraction for the efficient extraction of Praeruptorin A from Radix peucedani. J Sep Sci. 2014 37: 3539-3547.

34. Zhang Q, Zhao S, Chen J, Zhang L. Application of ionic liquidbased microwave-assisted extraction of flavonoids from Scutellaria baicalensis Georgi. J Chromatogr B. 2015; 1002: 411-417.

35. Duan L, Dou L, Guo L, Li P, Liu E. Comprehensive evaluation of deep eutectic solvents in extraction of bioactive natural products. ACS Sustain Chem Eng. 2016; 4(4): 2405-2411.

36. Leng KY, Suyin G. Natural deep eutectic solvent (NADES) as a greener alternative for the extraction of hydrophilic (Polar) and lipophilic (non-polar) phytonutrients. Key Eng Mater. 2019; 797(4): 20-28.

37. Farias FO, Pereira JFB, Coutinho JAP, Igarashi-Mafra L, Mafra MR Understanding the role of the hydrogen bond donor of the deep eutectic solvents in the formation of the aqueous biphasic systems. Fluid Phase Equilib. 2020; 503: 112319 
38. Vian M, Breil C, Vernes L, Chaabani E, Chemat F. Green solvents for sample preparation in analytical chemistry. Curr Opin Green Sustain Chem. 2017; 5: 44-48.

39. Liu Y, Li J, Fu R, Zhang L, Wang D, Wang S. Enhanced extraction of natural pigments from Curcuma longa L. using natural deep eutectic solvents. Ind Crops Prod. 2019; 140: 111620.

40. Ozturk B, Parkinson C, Gonzalez-Miquel M. Extraction of polyphenolic antioxidants from orange peel waste using deep eutectic solvents. Sep Purif Technol. 2018; 206: 1-13.

41. Pal CBT, Jadeja GC. Microwave-assisted deep eutectic solvent extraction of phenolic antioxidants from onion (Allium cepa L.) peel: a Box-Behnken design approach for optimization. J Food Sci Technol. 2019; 56(9): 4211-4223.

42. Gomez, A.V.; Tadini, C.C.; Biswas, A.; Buttrum, M.; Kim, S.; Boddu, V.M.; Cheng, H.N. Microwave-assisted extraction of soluble sugars from banana puree with natural deep eutectic solvents (NADES). LWT - Food Sci Technol. 2019; 107: 79-88.

43. Wang H, Ma X, Cheng Q, Xi X, Zhang L. Deep eutectic solventbased microwave-assisted extraction of baicalin from Scutellaria baicalensis Georgi. J Chem. 2018; 2018: 1-11.

44. Sahin S, Samli R. Optimization of olive leaf extract obtained by ultrasound-assisted extraction with response surface methodology. Ultrason Sonochem. 2013; 20(1): 595-602.

\section{GRAPHICAL ABSTRACT}

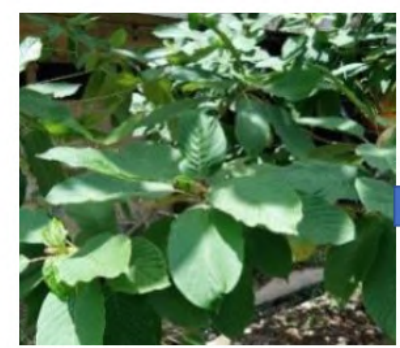

Mitragyna speciosa Korth Havil

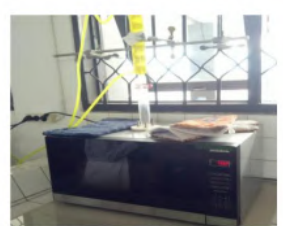

NADES-MAE Methods

\section{Extraction Process}

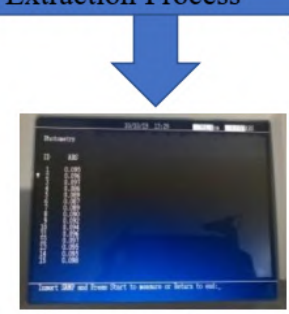

Total Polyphenolic Content (TPC)
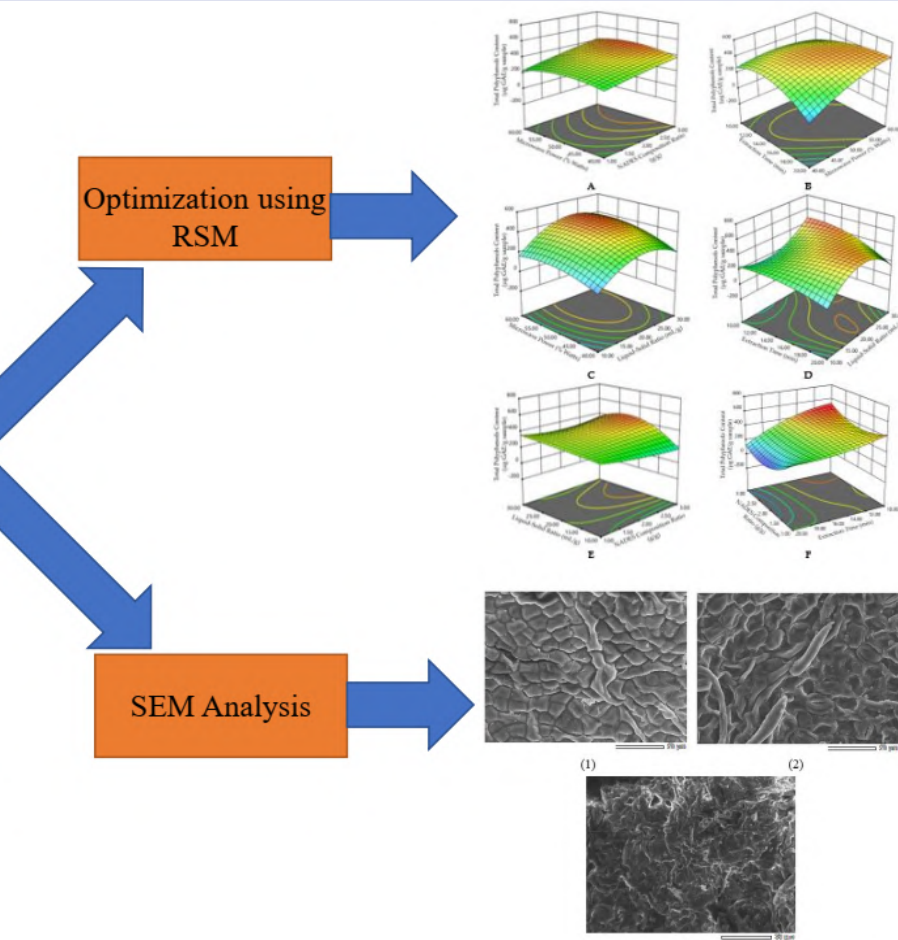

(3)

\section{SUMMARY}

1. The results show that the MANDESE with some different combinations of NADES composition is more effective than a maceration.

2. SEM imaging result shows that the levels of damage of cells and cell walls were more severe after extraction.

3. The optimum extraction condition has obtained the NADES composition ratio of $3 \mathrm{~g} / \mathrm{g}$ (choline chloride/sorbitol) and the liquid-solid ratio of $20 \mathrm{~mL} / \mathrm{g}$ for 20 min extraction time with $60 \%$ Watts microwave power.

4. The scale-up confirmation test was obtained the total polyphenols content of $526.12 \mu \mathrm{g} \mathrm{GAE} / \mathrm{g}$ sample. 


\section{ABOUT AUTHORS}
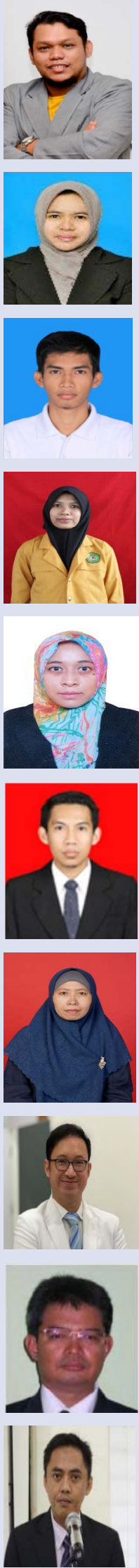

Wisnu Cahyo Prabowo, a doctoral student at the Department of Pharmaceutical Sciences, Faculty of Pharmacy, Universitas Padjadjaran, Bandung, West Java, Indonesia. As a lecturer and researcher at Faculty of Pharmacy, Universitas Mulawarman, Samarinda, East Kalimantan Indonesia. Research interest in Natural Products

Risna Agustina, a doctoral student at Faculty of Pharmacy, Universitas Padjadjaran, Bandung West Java, Indonesia. As a lecturer at Faculty of Pharmacy, Universitas Mulawarman, Samarinda, East Kalimantan, Indonesia. Research interest in Clinical and Community Pharmacy

Yuspian Nur, a doctoral candidate at the Department of Chemistry, Faculty of Mathematics and Natural Sciences, Universitas Padjadjaran, Bandung, West Java, Indonesia. As a lecturer and researcher at the Faculty of Pharmacy, Universitas Mulawarman. Research interest in the development of sensor and biosensors, also focusing on analytical chemistry.

Ramila Hidayati, an undergraduate student at the Faculty of Pharmacy, Universitas Mulawarman. Research interest in natural product chemistry.

Dewi Rahmawati, a lecturer at Faculty of Pharmacy, Universitas Mulawarman, Samarinda, East Kalimantan, Indonesia. Research interest in Clinical and Community Pharmacy.

M. Arifuddin, a lecturer and researcher at Department of Pharmaceutical Sciences, Faculty of Pharmacy, Universitas Mulawarman, Samarinda, East Kalimantan, Indonesia. He has an interest in natural products and microbiology, especially isolation compound of endofit fungi from plants

Dr. Neneng Siti Silfi Ambarwati, a Lecturer and Researcher at Cosmetology Department, Faculty of Engineering, Universitas Negeri Jakarta, East Jakarta, Indonesia. The research focused on natural products for drug and cosmetic discovery and development, extraction technology, and cosmetic ingredients (cosmeceuticals).

Dr. Reza Yuridian Purwoko, a lecturer in Indonesian Defense University and has been appointed as RnD Vice President of National Agriculture PT under supervision of Indonesian Ministry of Defence for National program of herbal medicine. He is also working as a researcher at Clinical Research Supporting Unit - Indonesian Medical Education and Research Institute Faculty Medicine University of Indonesia Jakarta.

Dr. Abdul Mun'im, a Professor of Natural Products at Faculty of Pharmacy, Universitas Indonesia, Depk, West Java, Indonesia. He has experience in the area of pharmacognosy ans phytochemistry, working in drugs discovery of herbal plants, estraction engineering, metabolite profiling, structure elucidation, and degenerative diseases (such as diabetes mellitus, antihypertension, and cholesterol)

Dr. Islamudin Ahmad, Associate Professor at Department of Pharmaceutical Sciences, Faculty of Pharmacy, Universitas Mulawarman, East Kalimantan, Indonesia. He has experience in Pharmacognosy and Natural Product Chemistry, working in drug discovery of natural products, green extraction engineering, isolation and identification of active compounds, screening biological activity mainly at degenerative diseases. 